\title{
Tropicibacter naphthalenivorans gen. nov., sp. nov., a polycyclic aromatic hydrocarbon-degrading bacterium isolated from Semarang Port in Indonesia
}

\author{
Correspondence \\ Yuki Kasai \\ ykasai@kitasato-u.ac.jp
}

\author{
Theresia Umi Harwati, ${ }^{1,2}$ Yuki Kasai, ${ }^{1}$ Yumiko Kodama, ${ }^{1}$ \\ Dwi Susilaningsih $^{2}$ and Kazuya Watanabe ${ }^{1}$ \\ ${ }^{1}$ Marine Biotechnology Institute, 3-75-1 Heita, Kamaishi, Iwate 026-0001, Japan
${ }^{2}$ Research Centre for Biotechnology, Indonesia Institute of Sciences (LIPI), Cibinong 11691 ,
Indonesia
}

An aerobic, Gram-negative, motile bacterium, strain $\mathrm{C}^{\top}{ }^{\top}$, was isolated from seawater obtained from Semarang Port in Indonesia. Cells of strain $\mathrm{C}_{0}{ }^{\top}$ were peritrichously flagellated and rodshaped. Strain $\mathrm{C}^{\top}{ }^{\top}$ was able to degrade naphthalene, alkylnaphthalenes and phenanthrene. $16 \mathrm{~S}$ rRNA gene sequence analysis revealed that this strain was affiliated with the family

Rhodobacteraceae in the class Alphaproteobacteria and was related most closely to Marinovum algicola FF3 ${ }^{\top}$ (95.7\% similarity) and Thalassobius aestuarii JC2049 ${ }^{\top}$ (95.2\%). The DNA G +C content of strain $\mathrm{C}_{0} 2^{\top}$ was $64.6 \mathrm{~mol} \%$. The major cellular fatty acids were $\mathrm{C}_{18: 1} \omega 7 \mathrm{c}$ ( $50.9 \%$ of the total), $\mathrm{C}_{16: 0}(17.9 \%), 11$ methyl $\mathrm{C}_{18: 1} \omega 7 c(14.7 \%), \mathrm{C}_{18: 1} \omega 9 c(2.9 \%)$ and $\mathrm{C}_{19: 0}$ cyclo $\omega 8 c$ $(2.4 \%)$, and the predominant respiratory lipoquinone was ubiquinone-10. Based on physiological, chemotaxonomic and phylogenetic data, strain $\mathrm{C}^{2}{ }^{\top}$ is suggested to represent a novel species of a new genus, for which the name Tropicibacter naphthalenivorans gen. nov., sp. nov. is proposed. The type strain of Tropicibacter naphthalenivorans is $\mathrm{CO}^{\top}\left(=\mathrm{JCM} 14838^{\top}=\mathrm{DSM} 19561^{\top}\right)$.
Contamination of the marine environment with petroleum hydrocarbons is of great public concern owing to their toxicity to humans and marine organisms (Malins et al., 1985; Meador et al., 1995). A number of hydrocarbondegrading bacteria have been isolated from the marine environment and characterized (e.g. Kasai et al., 2002a, b; Ozaki et al., 2006), although information regarding hydrocarbon-degrading bacteria from tropical waters is relatively scarce (Chaillan et al., 2004; Zhuang et al., 2003; Zinjarde \& Pant, 2002). We have recently isolated a substantial number of marine bacteria from seawater obtained from Semarang Port in Indonesia, and demonstrated that some of the isolates were capable of degrading hydrocarbons (Harwati et al., 2007). The present study characterizes one of these Indonesian isolates, designated strain $\mathrm{C}_{2} 2^{\mathrm{T}}$, affiliated with the class Alphaproteobacteria. Based on the results of polyphasic examinations, including phenotypic, chemotaxonomic and phylogenetic analyses, we propose that this strain represents a novel species of a new genus.

The ability of strain $\mathrm{C}_{0} 2^{\mathrm{T}}$ to degrade hydrocarbons in crude oil was examined in $10 \mathrm{ml}$ ONR7a medium (Dyksterhouse et al., 1995) supplemented with $1 \mathrm{mg}$ heat-treated Arabian Light crude oil $\mathrm{ml}^{-1}$ (Dutta \&

The GenBank/EMBL/DDBJ accession number for the 16S rRNA gene sequence of strain $\mathrm{CO}^{\top}$ is $\mathrm{AB} 302370$.
Harayama, 2000). Cells of strain $\mathrm{C}_{0} 2^{\mathrm{T}}$ grown in $10 \mathrm{ml}$ marine broth 2216 (MB; Difco) up to an optical density at $600 \mathrm{~nm}$ of approximately 1 were harvested by centrifugation $(8000 \mathrm{~g}, 10 \mathrm{~min})$, washed twice with ONR7a medium and inoculated on to the medium in $50-\mathrm{ml}$ tubes fitted with Teflon-lined caps. The tubes were incubated at $30{ }^{\circ} \mathrm{C}$ on a reciprocal shaker (at 90 r.p.m.) for 4 weeks. Cultures were prepared in triplicate. Non-inoculated samples were incubated similarly and served as controls. Following incubation, oil components were extracted by using chloroform, and hydrocarbon losses were analysed via GC-MS (GC-MS-QP5000; Shimadzu) as described by Kasai et al. (2002b). The percentage biodegradation was calculated as described by Dutta \& Harayama (2000). Strain $\mathrm{C}_{0} 2^{\mathrm{T}}$ degraded $88.1 \pm 1.1 \%($ mean $\pm \mathrm{SE})$ of total naphthalene, $56.0 \pm 10.4 \%$ of total $\mathrm{C}_{1}$-alkylnaphthalenes, $22.5 \pm 8.6 \%$ of total $\mathrm{C}_{2}$-alkylnaphthalenes and $14.5 \pm 2.7 \%$ phenanthrene, while alkanes, $\mathrm{C}_{3-4}$-alkylnaphthalenes, $\mathrm{C}_{0-4}$ alkyldibenzothiophenes, $\mathrm{C}_{1-6}$-alkylphenanthrenes and $\mathrm{C}_{0-3^{-}}$ alkylfluorenes were not significantly degraded $(<10 \%)\left(\mathrm{C}_{0}-\right.$ $\mathrm{C}_{6}$ represent total carbon numbers of branched alkyl groups).

The cell morphology of strain $\mathrm{C} 2^{\mathrm{T}}$ was examined by transmission electron microscopy (Beveridge et al., 1994) and motility was examined under a phase-contrast microscope. Gram staining and oxidase and catalase tests 
were performed according to the procedures of Smibert \& Krieg (1994). Growth was tested at $30{ }^{\circ} \mathrm{C}$ in $\mathrm{MB}$ unless otherwise stated. Salinity requirements were tested by using modified MB (Sohn et al., 2004) supplemented with 0-20\% $(\mathrm{w} / \mathrm{v}) \mathrm{NaCl}$ at $30{ }^{\circ} \mathrm{C}$. The $\mathrm{pH}$ range for optimal growth was determined on solid media containing $\mathrm{MB}$ whose $\mathrm{pH}$ was adjusted to 5.5-9.5. Solid media contained $1.5 \%(\mathrm{w} / \mathrm{v})$ Bactoagar (Difco). The presence of poly- $\beta$-hydroxyalkanoate was detected by using Sudan Black according to the procedures of de Lima et al. (1998). Susceptibility to antibiotics was determined on agar plates containing $\mathrm{MB}$ (MA plates) in the presence of the following antibiotics (concentrations given in parentheses; $\mu \mathrm{g} \mathrm{ml}^{-1}$ ): ampicillin (50, 100, 150 and 200), chloramphenicol (20), gentamicin (50), kanamycin sulfate (20), nalidixic acid (20,50, 100 and 200), spectinomycin (7.5, 15 and 20), streptomycin (20) and tetracycline (10). API ZYM, API 20NE (bioMérieux) and Microlog GN2 microplates (Biolog) were used for physiological and biochemical characterization according to the manufacturers' instructions.

Cells of strain $\mathrm{C}_{2}{ }^{\mathrm{T}}$ were Gram-negative rods $(1.1-3.4 \mu \mathrm{m}$ in length and $0.1-0.7 \mu \mathrm{m}$ in width), motile by means of peritrichous flagella (Fig. 1). Strain $\mathrm{C}_{2}{ }^{\mathrm{T}}$ formed white colonies on MA plates. The strain was oxidase-positive but catalase-negative. It reduced nitrate to nitrite. Cells contained poly- $\beta$-hydroxyalkanoate. Growth of strain $\mathrm{C} 02^{\mathrm{T}}$ was observed between 10 and $43{ }^{\circ} \mathrm{C}$, with optimum

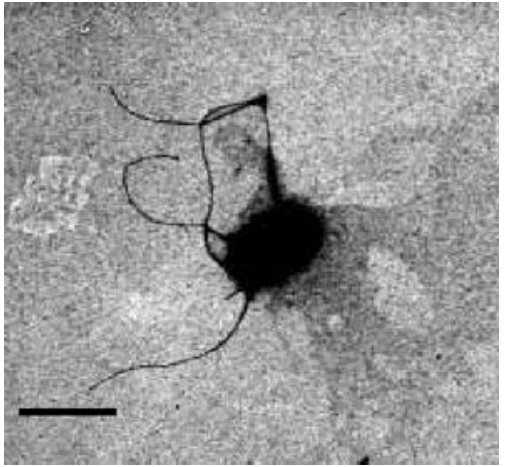

Fig. 1. Transmission electron micrograph of a cell of strain $\mathrm{CO}^{\top}$. Bar, $1 \mu \mathrm{m}$.

growth at $37^{\circ} \mathrm{C}$. It grew within a pH range of 6.5-8.5, with optimum growth at $\mathrm{pH}$ 7.6. Strain $\mathrm{C}_{2} 2^{\mathrm{T}}$ showed essential requirements for $\mathrm{NaCl}$, as no growth was observed in media lacking $\mathrm{NaCl}$. It grew at $\mathrm{NaCl}$ concentrations from 1 to $15 \%$, with optimum growth at $5 \% \mathrm{NaCl}$. The physiological and biochemical characteristics of strain $\mathrm{C}^{\mathrm{T}}{ }^{\mathrm{T}}$ are presented in detail in the species description below. It was susceptible to ampicillin, chloramphenicol, gentamicin, nalidixic acid, kanamycin, spectinomycin, streptomycin and tetracycline.

Table 1. Cellular fatty acid contents of strain $\mathrm{C} 2^{\top}$ and closely related taxa

Taxa: 1, strain $\mathrm{C}_{2}{ }^{\mathrm{T}}$; 2, Antarctobacter heliothermus EL-219 (data from Labrenz et al., 1998); 3, Sagittula stellata E-37 ${ }^{\mathrm{T}}$ (Gonzalez et al., 1997); 4, Ruegeria atlantica $1480^{\mathrm{T}}$ (Rüger \& Höfle, 1992); 5, Marinovum algicola $\mathrm{FF}^{\mathrm{T}}$ (Lafay et al., 1995; Martens et al., 2006); 6, Thalassobius aestuarii JC2049 ${ }^{\mathrm{T}}$ (Yi \& Chun, 2006); 7, Roseovarius tolerans EL-172 ${ }^{\mathrm{T}}$ (Labrenz et al., 1999); 8, Roseobacter denitrificans DSM 7001 ${ }^{\mathrm{T}}$ (Labrenz et al., 1999); 9, Phaeobacter daeponensis $\mathrm{TF}-218^{\mathrm{T}}$ (Yoon et al., 2007). Values are percentages of the total fatty acids; components that represented $<0.5 \%$ in all strains were omitted. ND, Not detected.

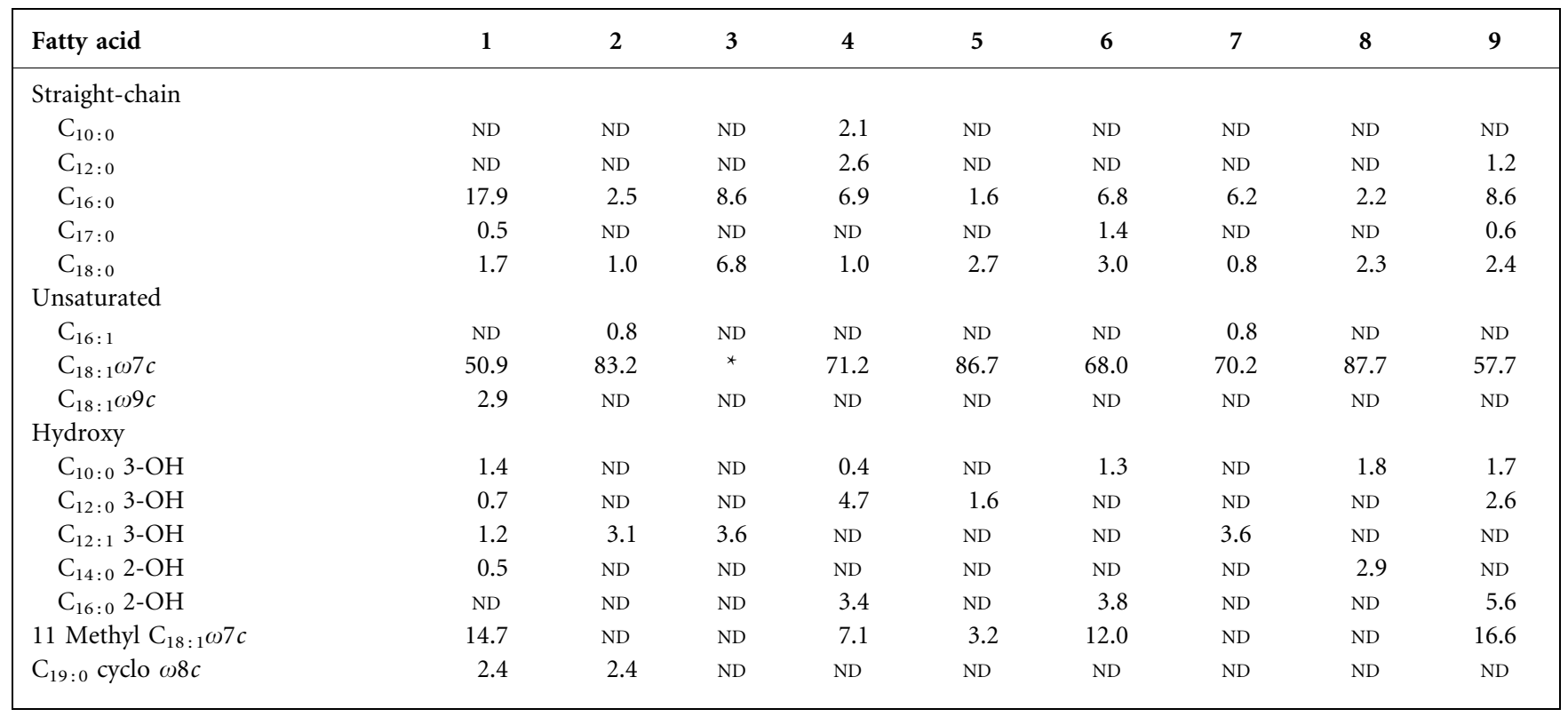

${ }^{*}$ Major fatty acid, but not quantified. 
Cellular fatty acids and quinone were analysed at the TechnoSuruga Laboratory Co., Ltd from cells grown in MB for $24 \mathrm{~h}$. The major cellular fatty acids of strain $\mathrm{C}^{2} 2^{\mathrm{T}}$ were $\mathrm{C}_{18: 1} \omega 7 c$ (50.9\% of the total), $\mathrm{C}_{16: 0}(17.9 \%), 11$ methyl $\mathrm{C}_{18: 1} \omega 7 c(14.7 \%), \mathrm{C}_{18: 1} \omega 9 c(2.9 \%)$ and $\mathrm{C}_{19: 0}$ cyclo $\omega 8 c$ $(2.4 \%)$ (detailed results are given in Table 1). The major lipoquinone was ubiquinone-10 (approximately $88 \%$ of the total).

The 16S rRNA gene sequence of strain ${\mathrm{C} 02^{\mathrm{T}}}(1363 \mathrm{bp}$ ) was determined previously (Harwati et al., 2007). Searches for similar 16S rRNA gene sequences were conducted by using the GenBank and RDP (Maidak et al., 1999) databases. Phylogenetic analysis was performed by using CLUSTAL_X (version 1.83) (Thompson et al., 1997), and a phylogenetic tree was constructed by using the neighbour-joining plot program within the MEGA software package (version 3.0) (Kumar et al., 2004). In the neighbour-joining phylogen- etic tree, strain $\mathrm{C}_{0} 2^{\mathrm{T}}$ formed a separate branch within the family Rhodobacteraceae (Fig. 2). 16S rRNA gene sequence analysis revealed that strain $\mathrm{C} 02^{\mathrm{T}}$ was related most closely to Marinovum algicola $\mathrm{FF}^{\mathrm{T}}(95.7 \%$ similarity) and Thalassobius aestuarii $\mathrm{JC} 2049^{\mathrm{T}}(95.2 \%)$. The latter two taxa belong to the Roseobacter clade, which is known as one of the most abundant groups in the marine environment (Buchan et al., 2005). The DNA G + C content of strain $\mathrm{C} 2^{\mathrm{T}}$ as determined by the method of Katayama-Fujimura et al. (1984) was $64.6 \mathrm{~mol} \%$.

Phenotypic characteristics of strain $\mathrm{C} 02^{\mathrm{T}}$ that can be used to differentiate it from closely related members of the Roseobacter clade are detailed in Table 2. Based on phylogeny, fatty acid composition and phenotypic characteristics, we conclude that strain $\mathrm{C}_{2} 2^{\mathrm{T}}$ represents a novel species of a new genus, for which the name Tropicibacter naphthalenivorans gen. nov., sp. nov. is proposed.

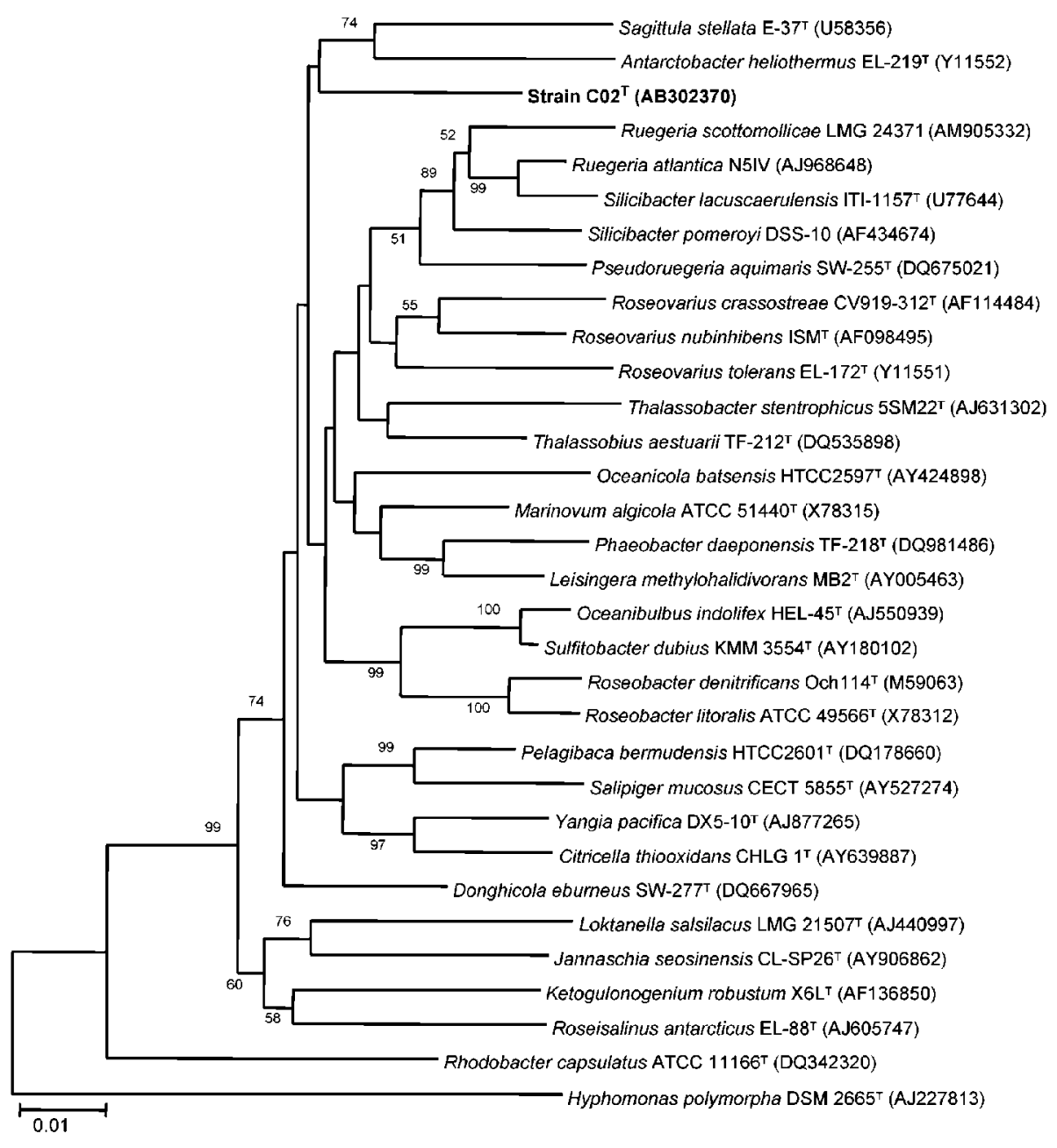

Fig. 2. Phylogenetic relationships between strain $\mathrm{CO} 2^{\top}$ and other members of the family Rhodobacteraceae. The tree was constructed by using the neighbour-joining algorithm. Numbers at nodes are bootstrap percentages based on 1000 replications; only values $>50 \%$ are shown. Bar, $1 \%$ estimated sequence divergence. 
Table 2. Differential phenotypic characteristics between strain $\mathrm{C} 02^{\top}$ and closely related taxa of the Roseobacter clade

Taxa: 1, strain $\mathrm{C}_{2}{ }^{\mathrm{T}}$; 2, Antarctobacter heliothermus EL-219 (data from Labrenz et al., 1998); 3, Sagittula stellata E-37 ${ }^{\mathrm{T}}$ (Gonzalez et al., 1997); 4, Ruegeria atlantica $1480^{\mathrm{T}}$ (Rüger \& Höfle, 1992); 5, Marinovum algicola $\mathrm{FF}^{\mathrm{T}}$ (Lafay et al., 1995; Martens et al., 2006); 6, Thalassobius aestuarii JC2049 ${ }^{\mathrm{T}}$ (Yi \& Chun, 2006); 7, Roseovarius tolerans EL-172 ${ }^{\mathrm{T}}$ (Labrenz et al., 1999); 8, Sulfitobacter dubius KMM 3554 ${ }^{\mathrm{T}}$ (Ivanova et al., 2004); 9, Roseobacter denitrificans Och $114^{\mathrm{T}}$ (Shiba, 1991); 10, Phaeobacter daeponensis TF-218 ${ }^{\mathrm{T}}$ (Yoon et al., 2007). +, Positive; -, negative; +/-, variable; ND, no data available; NF, not found; p, polar; sp, subpolar.

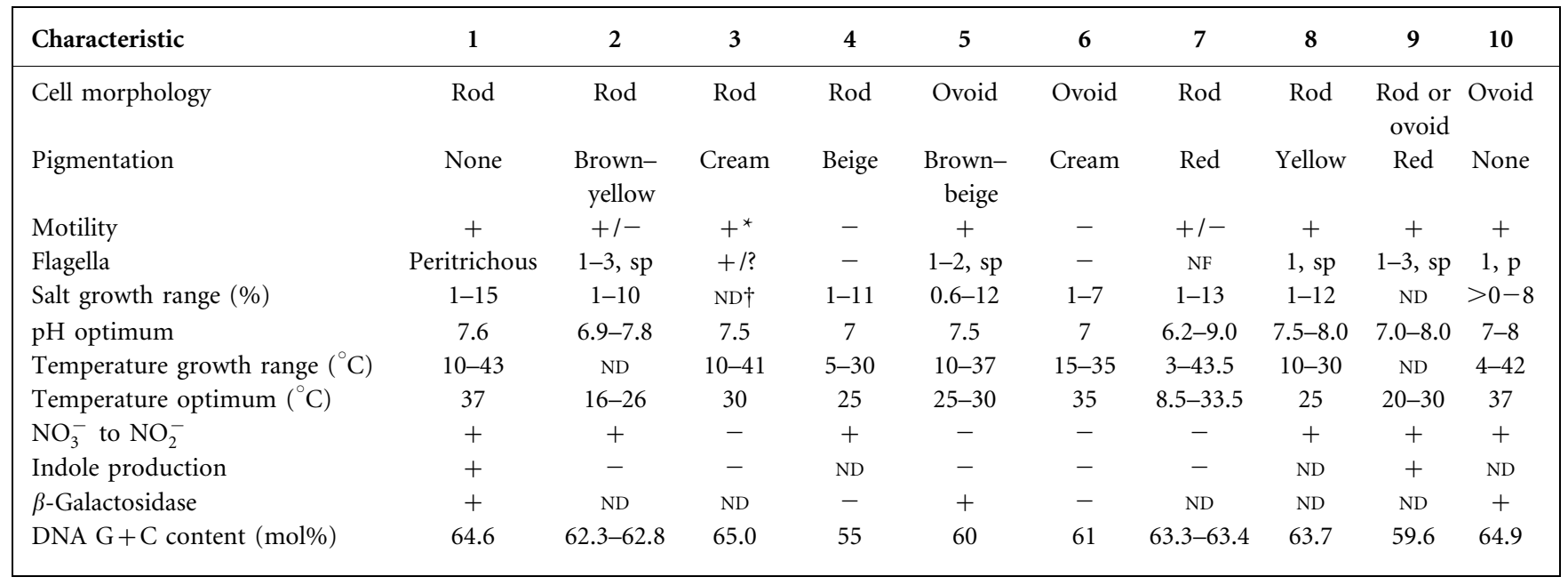

${ }^{*}$ Motility was assumed as flagella were found in suspension, but motile cells were not seen.

$\dagger$ Not determined, but required $\mathrm{NaCl}$ for growth (Gonzalez et al., 1997).

\section{Description of Tropicibacter gen. nov.}

Tropicibacter [Trop.ic.i.bac.ter. L. adj. tropicus tropical, pertaining to the tropical zone of the Earth; N.L. masc. n. bacter (from Gr. n. bakterion) rod; N.L. masc. n. Tropicibacter a rod belonging to the tropical zone].

Cells are Gram-negative, motile by means of peritrichous flagella and rod-shaped (1.1-3.4 $\mu \mathrm{m}$ long and $0.1-0.7 \mu \mathrm{m}$ wide). Require sodium ions for growth. Positive for oxidase and nitrate reduction. Contain poly- $\beta$-hydroxyalkanoate. The major ubiquinone is $\mathrm{Q}-10$. The predominant fatty acids are $\mathrm{C}_{18: 1} \omega 7 c, \mathrm{C}_{16: 0}$ and 11 methyl $\mathrm{C}_{18: 1} \omega 7 c$. The type species is Tropicibacter naphthalenivorans.

\section{Description of Tropicibacter naphthalenivorans sp. nov.}

Tropicibacter naphthalenivorans (naph.tha.le.ni.vo'rans. N.L. neut. N. naphthalenum naphthalene; L. part. adj. vorans devouring; N.L. part. adj. naphthalenivorans degrading naphthalene).

The description is identical to that for the genus, with the following additions. Colonies on MA are circular, slightly convex, smooth, yellowish-white and $2.0-3.0 \mathrm{~mm}$ in diameter after 3 days incubation at $37^{\circ} \mathrm{C}$. Growth occurs at temperatures of $10-43{ }^{\circ} \mathrm{C}$ (optimum $37{ }^{\circ} \mathrm{C}$ ), at $\mathrm{pH} 6.5$ 8.5 and at $\mathrm{NaCl}$ concentrations of $1-15 \%$ (optimum $5 \%$ ). Able to degrade $\mathrm{C}_{0-2}$-alkylnaphthalene and phenanthrene. Susceptible to $\left(\mu \mathrm{g} \mathrm{ml}^{-1}\right)$ ampicillin (50), chloramphenicol
(20), gentamicin (50), kanamycin (20), nalidixic acid (20), spectinomycin (7.5), streptomycin (20) and tetracycline (10). Positive for nitrate reduction, protease, esterase (C4), esterase lipase (C8), leucine arylamidase, valine arylamidase, acid phosphatase, naphthol-AS-BI-phosphohydratase, $\alpha$ galactosidase, $\beta$-galactosidase, $\alpha$-glucosidase and $\beta$-glucosidase. Negative for glucose fermentation, arginine dihydrolase, alkaline phosphatase, cystine arylamidase, trypsin, chymotrypsin, $\beta$-glucuronidase, $\alpha$-mannosidase and $\alpha$ fucosidase. The following Biolog GN2 test substrates score as positive: dextrin, Tween 80 , $\mathrm{L}$-arabinose, D-fructose, Dglucose, D-lactose, maltose, D-mannose, D-sorbitol, sucrose, lactic acid, succinic acid, L-aspartic acid, L-alanine, L-proline, serine, inosine, uridine, turanose, xylitol, trehalose, inosine, uridine, cellobiose, melibiose, L-rhamnose and acetic acid. The predominant fatty acids are $\mathrm{C}_{18: 1} \omega 7 c, \mathrm{C}_{16: 0}, 11$ methyl $\mathrm{C}_{18: 1} \omega 7 c, \mathrm{C}_{18: 1} \omega 9 c$ and $\mathrm{C}_{19: 0}$ cyclo $\omega 8 c$.

The type strain, $C 02^{\mathrm{T}}\left(=\mathrm{JCM} 14838^{\mathrm{T}}=\mathrm{DSM} 19561^{\mathrm{T}}\right)$, was isolated from seawater in Semarang Port, Java, Indonesia. The DNA $\mathrm{G}+\mathrm{C}$ content of the type strain is $64.6 \mathrm{~mol} \%$.

\section{Acknowledgements}

We are grateful to Professor H. G. Trüper for his help with the genus and species names. We thank Hiromi Awabuchi and Midori Satoh for their technical assistance. This work was supported by the Japan International Cooperation Agency (JICA) and Indonesian Institute of Sciences (LIPI). 


\section{References}

Beveridge, T. J., Popkin, T. J. \& Cole, R. M. (1994). Electron microscopy. In Methods for General and Molecular Bacteriology, pp. 42-71. Edited by P. Gerhardt, R. G. E. Murray, W. A. Wood \& N. R. Krieg. Washington, DC: American Society for Microbiology.

Buchan, A., Gonzalez, J. M. \& Moran, M. A. (2005). Overview of the marine Roseobacter lineage. Appl Environ Microbiol 71, 5665-5667.

Chaillan, F., Le Fleche, A., Bury, E., Phantavong, Y. H., Grimont, P., Saliot, A. \& Oudot, J. (2004). Identification and biodegradation potential of tropical aerobic hydrocarbon-degrading microorganisms. Res Microbiol 155, 587-595.

de Lima, T. C. S., Grisi, B. M. \& Bonato, M. C. M. (1999). Bacteria isolated from a sugarcane agroecosystem: their potential production of polyhydroxyalcanoates and resistance to antibiotics. Rev Microbiol 30, 214-224.

Dutta, T. K. \& Harayama, S. (2000). Fate of crude oil by the combination of photo-oxidation and biodegradation. Environ Sci Technol 34, 1500-1505.

Dyksterhouse, S. E., Gray, J. P., Herwig, R. P., Cano Lara, J. \& Staley, J. T. (1995). Cyclocasticus pugetii gen. nov., sp. nov., an aromatic hydrocarbon-degrading bacterium from marine sediments. Int J Syst Bacteriol 45, 116-123.

Gonzalez, J. M., Mayer, F., Moran, M. A., Hodson, R. E. \& Whitman, W. B. (1997). Sagittula stellata gen. nov., sp. nov., a lignin-transforming bacterium from a coastal environment. Int J Syst Bacteriol 47, 773-780.

Harwati, T. U., Kasai, Y., Kodama, Y., Susilaningsih, D. \& Watanabe, K. (2007). Characterization of diverse hydrocarbon-degrading bacteria isolated from Indonesian seawater. Microbes Environ 22, 412-415.

Ivanova, E. P., Gorshkova, N. M., Sawabe, T., Zhukova, N. V., Hayashi, K., Kurilenko, V. V., Alexeeva, Y., Buljan, V., Nicolau, D. V. \& other authors (2004). Sulfitobacter delicatus sp. nov. and Sulfitobacter dubius sp. nov., respectively from starfish (Stellaster equestris) and sea grass (Zostera marina). Int J Syst Evol Microbiol 54, 475-480.

Kasai, Y., Kishira, H. \& Harayama, S. (2002a). Bacteria belonging to the genus Cycloclasticus play a primary role in the degradation of aromatic hydrocarbons released in a marine environment. Appl Environ Microbiol 68, 5625-5633.

Kasai, Y., Kishira, H., Sasaki, T., Syutsubo, K., Watanabe, K. \& Harayama, S. (2002b). Predominant growth of Alkanivorax strains in oil-contamined nutrient-supplemented sea water. Environ Microbiol $4,141-147$

Katayama-Fujimura, Y., Komatsu, Y., Kuraishi, H. \& Kaneko, T. (1984). Estimation of DNA base composition by high performance liquid chromatography of its nuclease P1 hydrolysate. Agric Biol Chem 48, 3169-3172.

Kumar, S., Tamura, K. \& Nei, M. (2004). MEGA3: integrated software for molecular evolutionary genetics analysis and sequence alignment. Brief Bioinform 5, 150-163.

Labrenz, M., Collins, M. D., Lawson, P. A., Tindall, B. J., Braker, G. \& Hirsch, P. (1998). Antarctobacter heliothermus gen. nov., sp. nov., a budding bacterium from hypersaline and heliothermal Ekho Lake. Int J Syst Bacteriol 48, 1363-1372.

Labrenz, M., Collins, M. D., Lawson, P. A., Tindall, B. J., Schumann, P. \& Hirsch, P. (1999). Roseovarius tolerans gen. nov., sp. nov., a budding bacterium with variable bacteriochlorophyll $a$ production from hypersaline Ekho Lake. Int J Syst Bacteriol 49, 137-147.
Lafay, B., Ruimy, R., de Traubenberg, C. R., Breittmayer, V., Gauthier, M. J. \& Christen, R. (1995). Roseobacter algicola sp. nov., a new marine bacterium isolated from the phycosphere of the toxinproducing dinoflagellate Prorocenrum lima. Int J Syst Bacteriol 45, 290-296.

Maidak, B. L., Cole, J. R., Parker, C. T., Jr, Garrity, G. M., Larsen, N., Li, B., Lilburn, T. G., McCaughey, M. J., Olsen, G. J. \& other authors (1999). A new version of the RDP (Ribosomal Database Project). Nucleic Acids Res 27, 171-173.

Malins, D. C., Krahn, M. M., Brown, D. W., Rhodes, L. D., Myers, M. S., McCain, B. B. \& Chan, S. L. (1985). Toxic chemicals in marine sediment and biota from Mukilteo, Washington: relationships with hepatic neoplasms and other hepatic lesions in English sole (Parophrys vetulus). J Natl Cancer Inst 74, 487-494.

Martens, T., Heidorn, T., Pukall, R., Simon, M., Tindall, B. J. \& Brinkhoff, T. (2006). Reclassification of Roseobacter gallaeciensis RuizPonte et al. 1998 as Phaeobacter gallaeciensis gen. nov., comb. nov., description of Phaeobacter inhibens sp. nov., reclassification of Ruegeria algicola (Lafay et al. 1995) Uchino et al. 1999 as Marinovum algicola gen. nov., comb. nov., and emended descriptions of the genera Roseobacter, Ruegeria and Leisingera. Int J Syst Evol Microbiol 56, 1293-1304.

Meador, J. P., Stein, J. E., Reichert, W. L. \& Varanasi, U. (1995). Bioaccumulation of polycyclic aromatic hydrocarbons by marine organisms. Rev Environ Contam Toxicol 143, 79-165.

Ozaki, S., Kishimoto, N. \& Fujita, T. (2006). Isolation and phylogenetic characterization of microbial consortia able to degrade aromatic hydrocarbons at high rates. Microbes Environ 21, 44-52.

Rüger, H. J. \& Höfle, M. G. (1992). Marine star-shaped-aggregateforming bacteria: Agrobacterium atlanticum sp. nov.; Agrobacterium meteori sp. nov.; Agrobacterium ferrugineum sp. nov., nom. rev.; Agrobacterium gelatinovorum sp. nov., nom. rev.; and Agrobacterium stellulatum sp. nov., nom. rev. Int J Syst Bacteriol 42, 133-143.

Shiba, T. (1991). Roseobacter litoralis gen. nov., sp. nov., and Roseobacter denitrificans sp. nov., aerobic pink-pigmented bacteria which contain bacteriochlorophyll a. Syst Appl Microbiol 14, 140-145.

Smibert, R. M. \& Krieg, N. R. (1994). Phenotypic characterization. In Methods for General and Molecular Bacteriology, pp. 607-655. Edited by P. Gerhardt, R. G. E. Murray, W. A. Wood \& N. R. Krieg. Washington, DC: American Society for Microbiology.

Sohn, J. H., Kwon, K. K., Kang, J.-H., Jung, H.-B. \& Kim, S.-J. (2004). Novosphingobium pentaromatovorans sp. nov., a high-molecular-mass polycyclic aromatic hydrocarbon-degrading bacterium isolated from estuarine sediment. Int J Syst Evol Microbiol 54, 1483-1487.

Thompson, J. D., Gibson, T. J., Plewniak, K., Jeanmougin, F. \& Higgins, D. G. (1997). The CLUSTAL_X windows interface: flexible strategies for multiple sequence alignment aided by quality analysis tools. Nucleic Acids Res 25, 4876-4882.

Yi, H. \& Chun, J. (2006). Thalassobius aestuarii sp. nov., isolated from tidal flat sediment. J Microbiol 44, 171-176.

Yoon, J.-H., Kang, S.-J., Lee, S.-Y. \& Oh, T.-K. (2007). Phaeobacter daeponensis sp. nov., isolated from a tidal flat of the Yellow Sea in Korea. Int J Syst Evol Microbiol 57, 856-861.

Zhuang, W. Q., Tay, J. H., Maszenan, A. M. \& Tay, S. T. (2003). Isolation of naphthalene-degrading bacteria from tropical marine sediments. Water Sci Technol 47, 303-308.

Zinjarde, S. S. \& Pant, A. A. (2002). Hydrocarbon degraders from tropical marine environments. Mar Pollut Bull 44, 118-121. 